\title{
The Impact of Social Factors on Macroeconomic Stability: Empirical Evidence for Ukraine and European Union Countries
}

Maksim Palienko

$\mathrm{PhD}$, University of Insurbia, Como, Italy

\section{Oleksii Lyulyov}

$\mathrm{PhD}$, Associate Professor, Department of Economics and Business Administration, Sumy State University, Ukraine

\begin{abstract}
The main objective of the paper is to study the role and power of the influence of social factors on macroeconomic stability. The integral indicator of human capital is suggested that allows to consider social factors that need urgent attention from the position of a potential source of increasing macroeconomic stability in the context of the future of the European vector of development of Ukraine. A block diagram is proposed for estimating the integral index of human capital, which consists of five main stages. The results of the work testify to the presence of a positive and statistically significant connection at the level of $5 \%$ between social factors and macroeconomic stability of Ukraine in the period 2000-2015. Along with social factors, the openness of the economy and the volume of foreign direct investment are used to increase the accuracy of the model describing the dynamics of macroeconomic stability.
\end{abstract}

JEL Classification: E60, C19, O15, O20, O40.

Keywords: economic growth, macroeconomic stability, social factors, EU, index.

(C) The Authors, 2018. This article is published with open access at Sumy State University.

\section{Introduction}

The last global financial and economic crisis has led to an acceleration in the growth rates of disproportions in the socio-economic development of countries. The two main negative aspects of the impact of the crisis were the experience of high and stable rates of unemployment and the growth of social inequality (CastellsQuintana \& Royuela, 2012).

As shown in official statistical data in Figure 1, the European standard of living, measured by gross domestic product per capita in the period 2008-2016 remains statistically lower than in the pre-crisis period. Thus, during the period 2000-2007, the rate of GDP growth per capita in the EU countries averaged about 4\%. The most positive dynamics of this indicator on average for 2000-2007 demonstrated the economy of Latvia (9.67\%), Lithuania $(8.73 \%)$, Estonia $(8.5 \%)$, Bulgaria $(7.2 \%)$, Romania $(6.75 \%)$. It is noteworthy that the average unemployment rate for the analyzed period (7.16\%) in the countries mentioned only in Romania was lower than for the EU countries as a whole $(8.25 \%)$. In general, only 5 EU countries occupied positions in the upper quartile for both indicators the Czech Republic, Slovenia, Hungary, Ireland and Romania. These countries had the highest average growth rates of GDP per capita with a minimum level of unemployment (see Figure 1).

The trend of changes in the growth rates of GDP per capita $(Y)$ in the EU countries from the unemployment rate $(U n)$ for the period from 2000 to 2007 is described by the regression model (1):

$$
Y(U n)=6.1447850-0.2810339 \times U n
$$

The regression model indicates that the unemployment rate has a negative and very significant impact on the economic growth of the EU countries in the period 2000-2007. The main characteristics of the obtained regression model are given in Table 1.

The results of a panel analysis of the dependence of GDP growth rates per capita in the EU countries on the level of unemployment for the period from 2000 to 2007

\begin{tabular}{|c|c|c|c|c|c|}
\hline & Coef. & Std. Err. & $t$ & $P>|t|$ & [95\% Conf. Interval] \\
\hline$U n$ & -0.2810339 & 0.0561092 & -5.01 & 0.000 & $-0.3916926-0.1703752$ \\
\hline Const & 6.144785 & 0.474773 & 12.94 & 0.000 & 5.2084367 .081134 \\
\hline
\end{tabular}




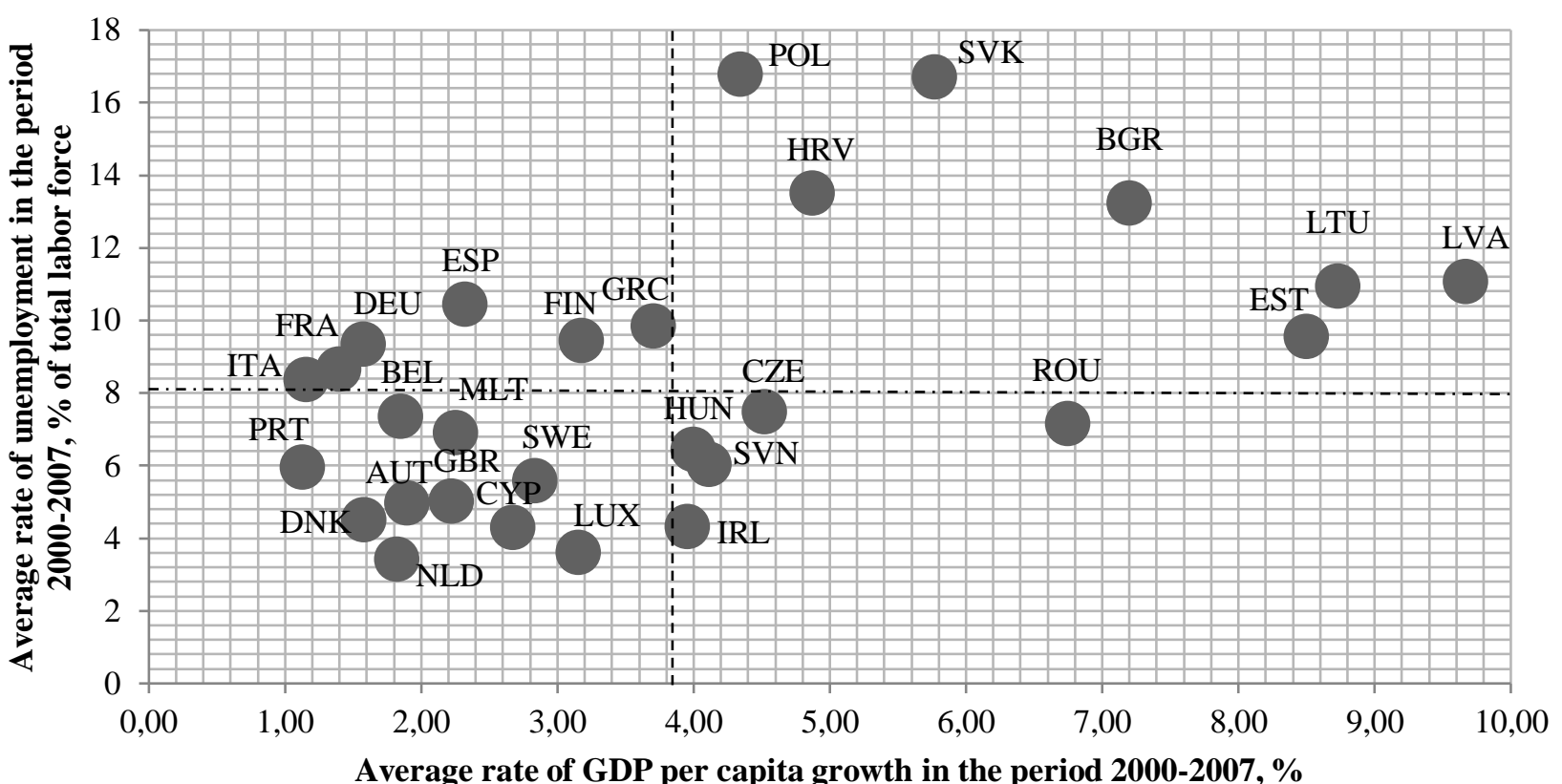

a)

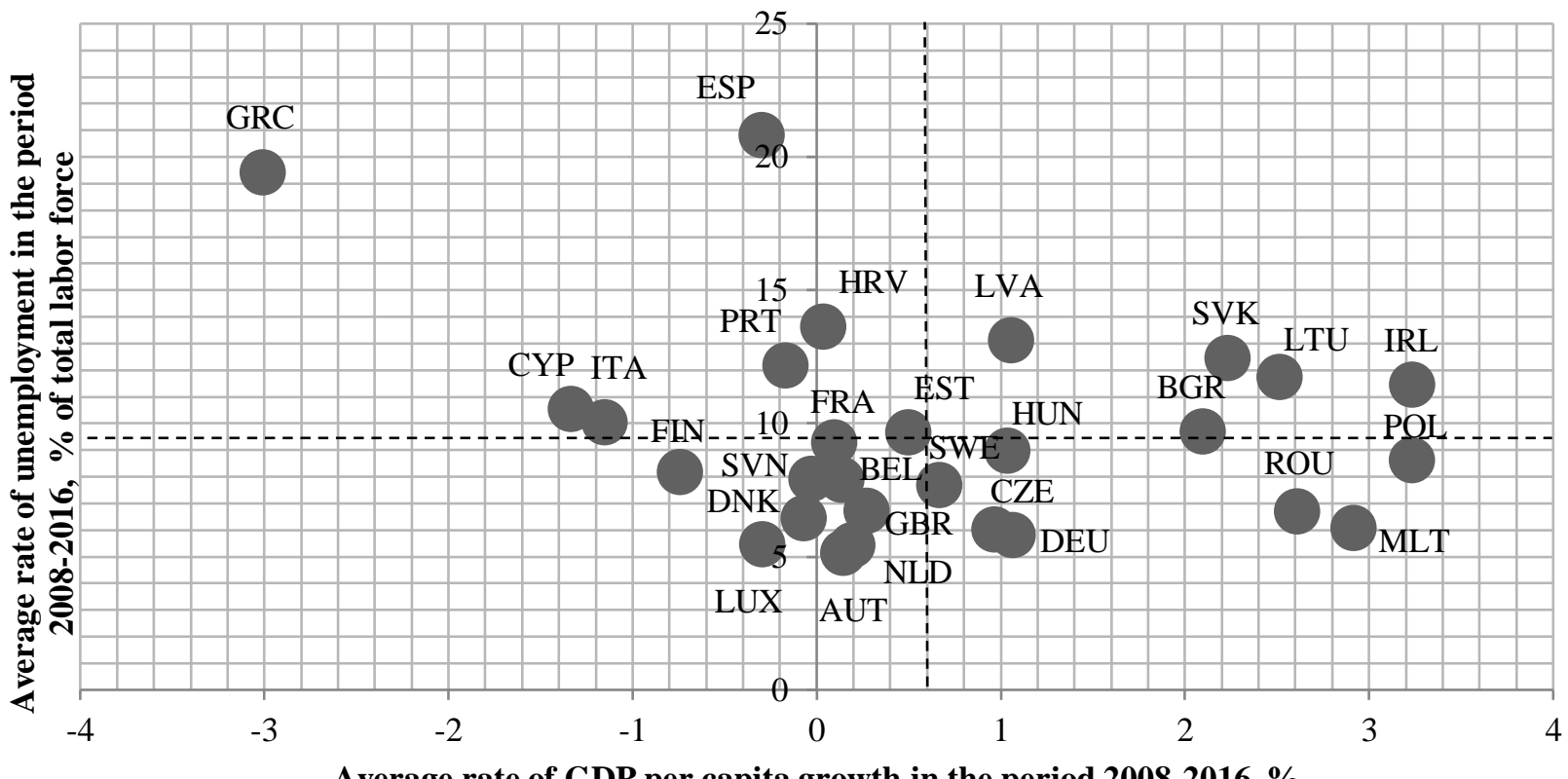

Average rate of GDP per capita growth in the period 2008-2016, \%

b)

Notes: Austria-AUT; Belgium-BEL; Bulgaria-BGR; Cyprus-CYP; Czech Republic-CZE; Germany-DEU; Denmark-DNK; SpainESP; Estonia-EST; Finland-FIN; France-FRA; United Kingdom-GBR; Greece-GRC; Croatia-HRV; Hungary-HUN; Ireland-IRL; Italy-ITA; Lithuania-LTU; Luxembourg-LUX; Latvia-LVA; Malta-MLT; Netherlands-NLD; Poland-POL; Portugal-PRT; Romania-ROU; Slovak Republic-SVK; Slovenia-SVN; Sweden-SWE.

Source: the authors' own calculations based on World data (World Bank, 2017)

Figure 1. Comparison of the average rates of economic growth per capita and unemployment in the member countries of the European Union: a) in 2000-2007, and b) in 2008-2016 years.

In the period from 2007 to 2016, the economies of the EU countries were in the greatest recession. So in the year 2009. From all EU countries only in Poland there was GDP growth per capita (2.75\%), significant negative changes occurred in Estonia (the fall in GDP per capita at $14.56 \%$ ), Lithuania (13.86\%), Latvia $(12.98 \%)$ and Slovenia (8.63\%). From 28 EU countries only 8 on a parity of indicators of growth of gross national product per capita and unemployment have occupied positions in the upper quartile. They are Swit- 
zerland, the Czech Republic, Germany, Hungary, Bulgaria, Romania, Malta and Poland. However, as noted above, the average level of GDP growth per capita in the EU countries was $0.64 \%$ in 2008-2016, which is almost six times less than in the pre-crisis period. From 2008 to 2016 the largest increase in this indicator, more than four times regarding the mean value for $28 \mathrm{EU}$ countries took place in Ireland (5.06\%), Malta (4.57\%), Poland (5.06\%), Romania 4.08\%).

According to the criteria proposed by the European Commission for the detection, prevention and emergence of potentially harmful macroeconomic imbalances that could adversely affect economic stability in the member states of the EU (European Commission, 2015), the excess of 10\% of the average unemployment rate for the last three years occurred in Greece (14.97\%), Spain (12.03\%), Croatia (5.53\%), Cyprus (4.67\%), Portugal $(2.47 \%)$, Slovakia (1.47\%), France $(0.27 \%)$. The lowest average annual unemployment rate in the last three years was recorded in Germany (4.57\%), Austria (5.77\%), Czechia (5.03\%), Great Britain (5.4\%), Malta (5.3\%).

In the period 2008-2016, the main characteristics of the regression model (2) of the dependence of GDP per capita $(Y)$ in the EU countries on the unemployment rate $(U n)$ are given in Table 2.

$Y(U n)=1.406869-0.0805075 \times U n$

Table 2. The results of a panel analysis of the dependence of GDP growth rates per capita in the EU countries on the rate of unemployment for the period from 2008 to 2016

\begin{tabular}{|c|c|c|c|c|c|}
\hline & Coef. & Std. Err. & $t$ & $P>|t|$ & {$[95 \%$ Conf. Interval] } \\
\hline Un & -0.0805075 & 0.0562327 & -1.43 & 0.152 & -0.19072170 .0297066 \\
\hline Const & 1.406869 & 0.6016552 & 2.34 & 0.019 & 0.22764662 .586092 \\
\hline
\end{tabular}

The transformations in Ukraine because of the global financial and economic crisis occurred in most aspects of public life such as the rate of employment, wages, incomes, or the amount of state spending for social purposes and the like. So the unemployment rate in 2016 increased by 3\% compared to 2007 and amounted to $9.4 \%$ or 1691.5 thousand people (Ukraine, 2017). A consequence of this negative trend was an increase in the unemployment rate among the population aged 15-24 (23\%). It should be noted that for the first time since 2007 this unemployment rate exceeded by $0.7 \%$ the average for the EU countries (in $2016-8.7 \%$ ). However, throughout the analyzed period only in 2002 the average unemployment rate exceeded $10 \%$ and amounted to $10.73 \%$ (see Figure 2).

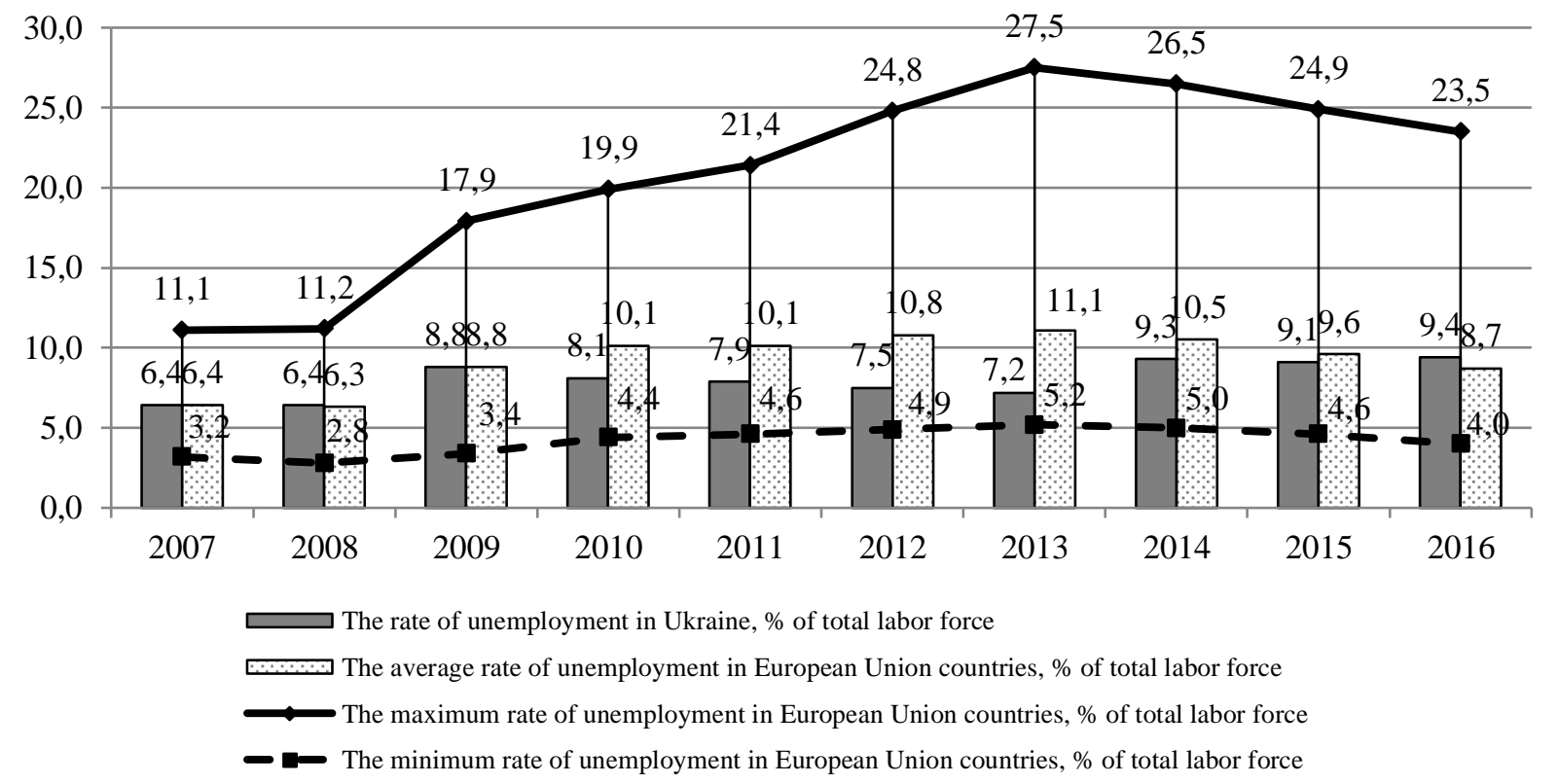

Figure 2. The comparison of the unemployment rate in Ukraine and the EU in the period 2007-2016

Source: the authors' own calculations based on World data (World Bank, 2017).

The level of average and minimum wages in the hryvnia equivalent since 2000 rapidly grew and amounted in 2017 to $6785 \mathrm{UAH}$ and $3200 \mathrm{UAH}$, respectively. But relative to the dollar there is an ambiguous trend according to Figure 3: in the period from 2000 to 2008 the level of minimum and average wages grew, and in 2014- 
2017 , due to the growth of the dollar, it rapidly declined to its minimum in 2016 (\$58), which corresponded to the level of 2005 (\$58). Its maximum level of minimum and average wages in the pre-crisis and after the crisis period reached in the years of constant marks of the dollar, so in 2008 its level was \$100 and \$342, and in 2013 it comprised $\$ 148$ and $\$ 410$ (see Figure 3). Among the EU countries, as of January 1, 2017 according to Eurostat (2017) the minimum wage was in Bulgaria (EUR 235), which was able to achieve a high relative growth since $2008(+109 \%)$ compared with the 22 EU member states in which the minimum level of wage is legally established. Ukraine according to the current trend of 2014-2017 and the level of the minimum wage falls several times behind the EU member states, in particular, with which it borders. So Poland and Romania were able to raise the minimum wage in 2014 from $12.3 \%$ to $44.74 \%$ (Poland from $404 €$ per month in 2014 to $453 €$ per month in 2017 as of January 1, Romania from $190 €$ to $275 €$ per month). In absolute terms, the highest level of the minimum wage as of January 1, 2017 was reached in Luxembourg (1999€ per month), and in Great Britain - an absolute growth (+146€ per month) (Eurostat, 2017).

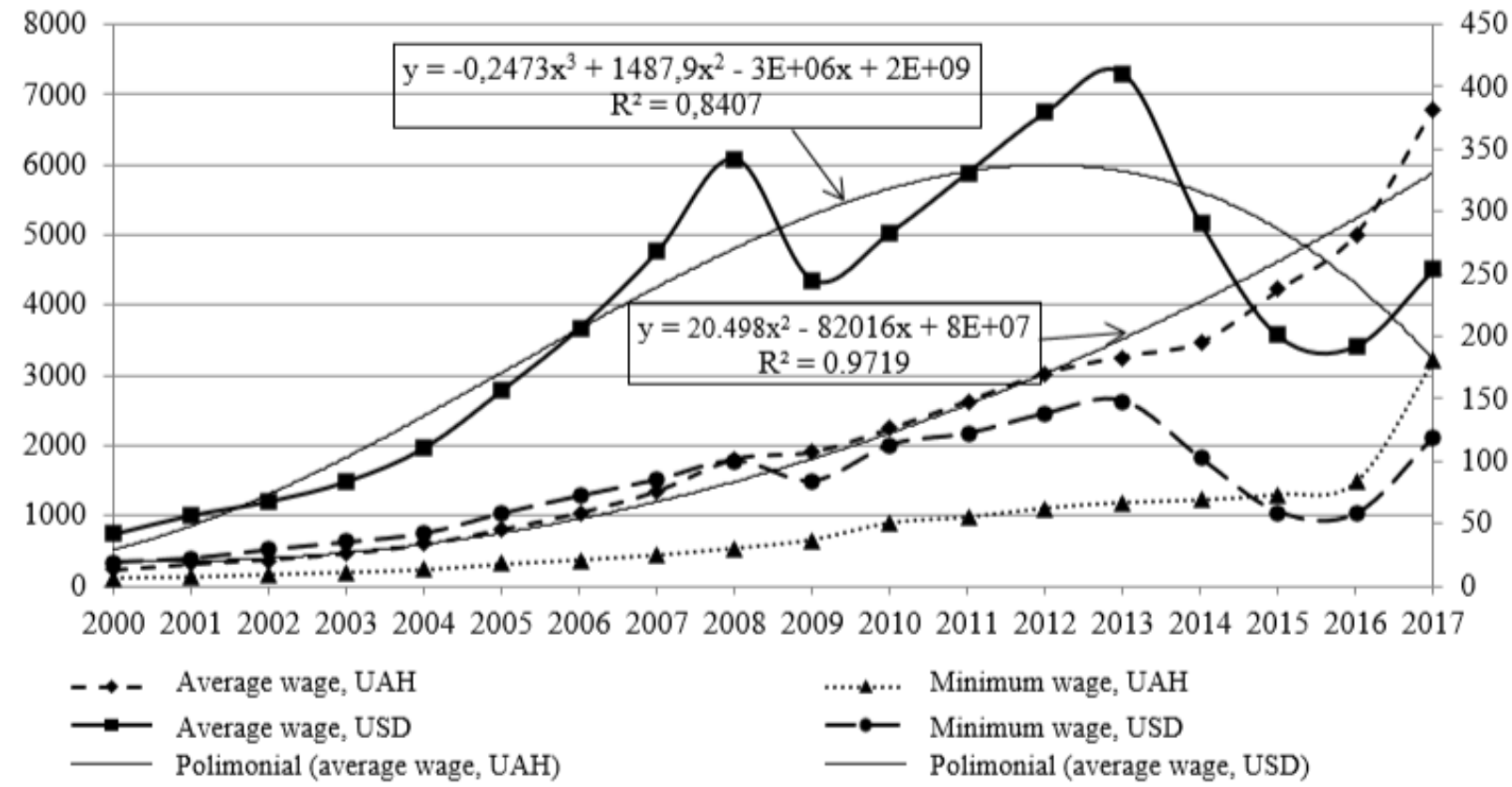

Figure 3. The dynamics of average and minimum wages in Ukraine for 2000-2017

Source: the authors' own calculations based on State statistics service of Ukraine (Ukrainy, 2017).

The inequality of income distribution has a significant negative impact on the country's economic growth (Cingano, 2014). Inequality hinders the political process and democratic governance because it generates the appearance of corruption due to the concentration of wealth and income in certain groups of people (You and Khagram, 2005). The Gini index is the most common measure of inequality, which is estimated on a scale from 0 (complete equality) to 100 (general inequality) (World of Work Report, 2008).

In 2015, Ukraine made significant progress in ensuring an even distribution of income among the population (the Gini index was 25.5). Comparing this indicator with the EU countries (see Figure 4) only Slovenia (24.5), Slovakia (23.7), Finland (25.2) and the Czech Republic (25) had a lower income inequality level than Ukraine. Bulgaria, Lithuania, Romania had the highest level of the Gini index in 2015, which exceeded the average for the EU by $6,6.9$ and 6.4 points, respectively.

The conducted correlation-regression analysis of the influence on the growth of Ukrainian GDP structure of the population by age in the period 1991-2016. It showed a statistically significant and positive relationship between GDP and the population aged 15-64 (Table 3). According to the data given in Table 3, it can be argued that along with other factors that need to be considered since the proposed model only describes the interdependence by 25\%, an increase in the structure of the population aged 15-64 can lead to an increase in GDP. 


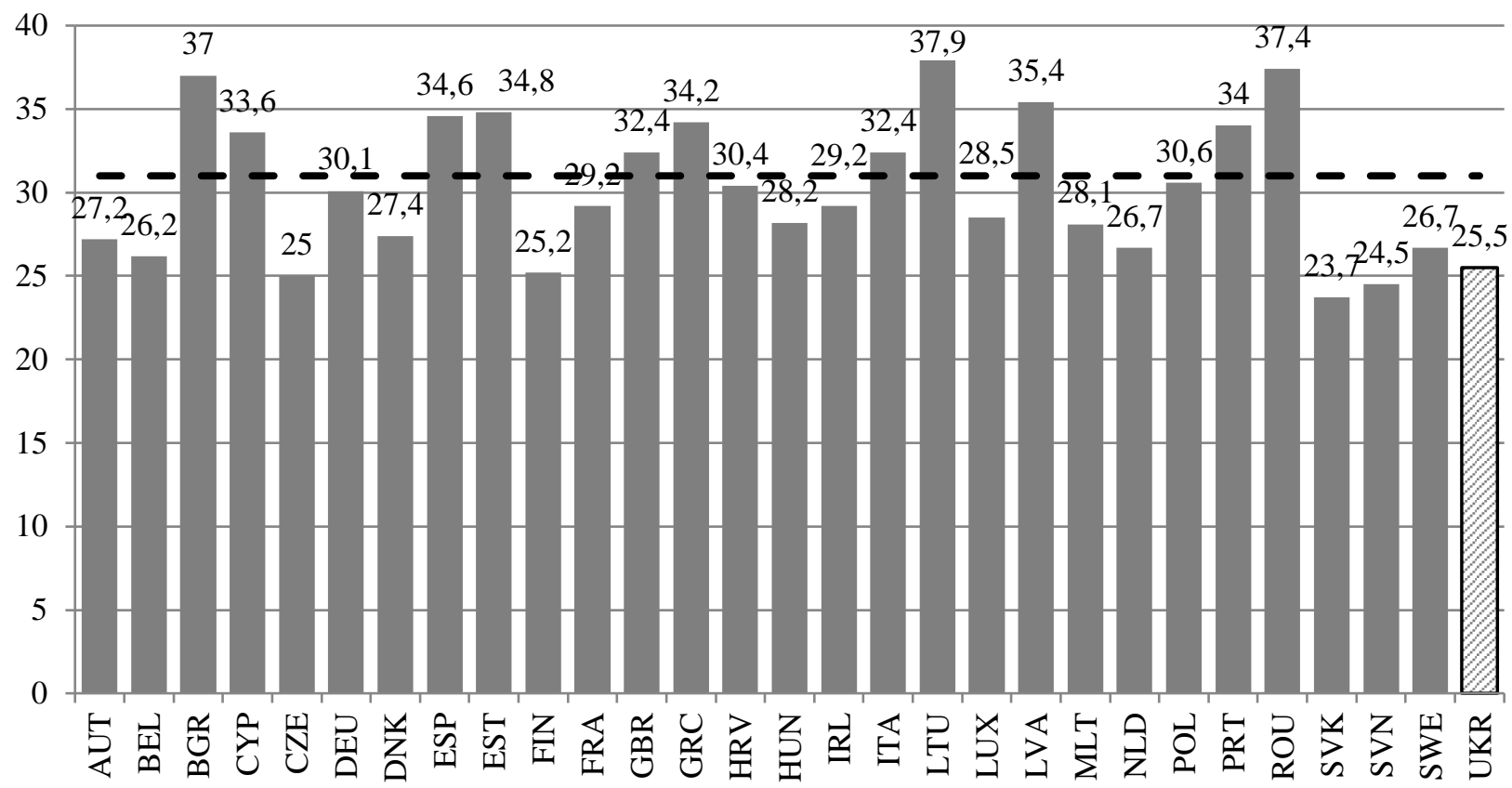

Notes: Austria-AUT; Belgium-BEL; Bulgaria-BGR; Cyprus-CYP; Czech Republic-CZE; Germany-DEU; Denmark-DNK; SpainESP; Estonia-EST; Finland-FIN; France-FRA; United Kingdom-GBR; Greece-GRC; Croatia-HRV; Hungary-HUN; Ireland-IRL; Italy-ITA; Lithuania-LTU; Luxembourg-LUX; Latvia-LVA; Malta-MLT; Netherlands-NLD; Poland-POL; Portugal-PRT; Romania-ROU; Slovak Republic-SVK; Slovenia-SVN; Sweden-SWE; Ukraine-UKR.

Source: the authors' own calculations based on Eurostat data (Eurostat, 2017).

Figure 4. Gini Coefficient (2015)

Table 3. The relationship between GDP and the population of Ukraine during 1991-2016

\begin{tabular}{r|rrr} 
Source & SS & df & MS \\
Model | & 2.07109762 & 1 & 2.07109762 \\
Residual | & 5.94261987 & 24 & .247609161 \\
$---0--1$ & \\
Total | & 8.01371749 & 25 & .320548699
\end{tabular}

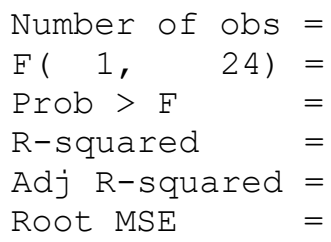

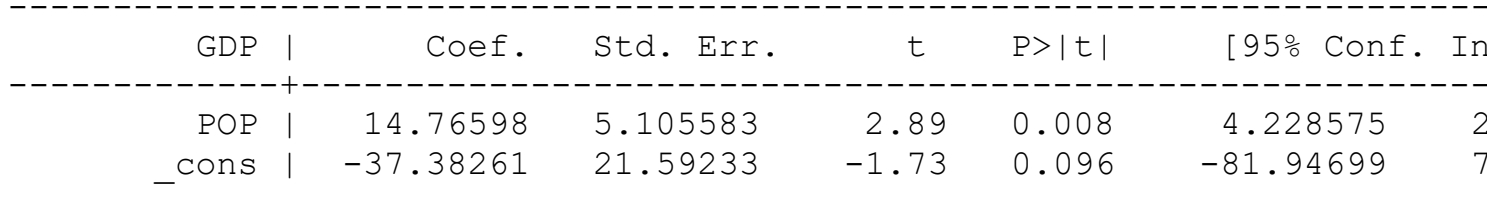

Source: the authors' own calculations based on World data (World Bank, 2017).

\section{Literature review}

Marco Buti, Director General for Economic and Financial Affairs at the European Commission in his work "Balancing Imbalances: Improving Economic Governance in the EU after the Crisis" notes that one of the main reasons for the negative impact of the recent financial and economic crisis on the economies of the EU member states was the accumulation of increasing macroeconomic instability (Buti, 2011).

Theoretical and applied prerequisites for the influence of social factors on macroeconomic indicators were comprehensively considered in the works of foreign scientists. Ana-Maria Popa uses an econometric model to test the direction and significance of social factors on the economic growth of the EU countries in the period 2005-2009 (Popa, 2012). The author uses the real GDP per capita as the dependent variable and the independent variables are: population at risk of poverty, unemployment rate, life expectancy and expected years of schooling. The result of the study was the confirmation of the hypothesis of the existence of a strong connection between the human and economic development of the country. In addition, for a more complete 
analysis, except the proposed parameters, in the opinion of the authors, additional financial, political and legislative factors are needed in the framework of each country under study.

More I. and Aye G.C. (More \& Aye, 2017) use the Cobb-Douglas production function (3) to show role of social infrastructure in economic growth and inequality in South Africa for the period 1994-2013.

$Y=f(G D C F, L F P R, E D U E X P, H E X P, T)$

where $Y$ - GDP per capita; GDCF - gross domestic capital formation; LFPR - labour force; EDUEXP education expenditure; HEXP - health expenditure; $\mathrm{T}$ - trade openness.

The authors come to the conclusion that there is a different orientation and power of influence on economic growth and inequality in spending on education and health (More \& Aye, 2017). So, for economic growth, the impact of spending on education was statistically significant and positive, and health care expenditure was negative and statistically insignificant. On inequality, education costs were expected to be negatively affected, but this dependence was statistically insignificant, as opposed to health expenditure had a significant and negative impact (More \& Aye, 2017).

Empirical research in the work "The impact of basic and social infrastructure investment on South African economic growth and development" recognizes that the basic and social infrastructure has a positive impact on economic growth and social development on South African (Gnade et al., 2017). The authors note that "the economic growth and social development return would be greater in rural municipalities" (Gnade et al., 2017).

David Castells-Quintana and Vicente Royuela (2012) investigated the relationship between economic development and unemployment. They found that along with rising income inequality high and stable rate of unemployment has a negative and significant effect on long-term economic growth. However, the authors note that "unemployment may seriously harm growth not only because it is a waste of resources, but also because it has serious distributional effects: it generates redistributive pressures and subsequent distortions; it depreciates existing human capital and deters its accumulation; it drives people to poverty; it results in liquidity constraints that limit labour mobility; and finally it erodes individual selfesteem and promotes social dislocation, unrest and conflict" (Castells-Quintana \& Royuela, 2012).

Mahmoud A. Al-Habees and Mohammed Abu Rumman (2012) claim that there is a significant correlation between economic growth and changing rates of unemployment in Jordan and Some Arab Countries. Main results of the study of Shatha Abdul-Khaliq, Thikraiat Soufan and Ruba Abu Shihab show that an increase in economic growth of $1 \%$ will lead to a decrease in the unemployment rate $0,16 \%$ (Abdul-Khaliq et al., 2014).

David E. Bloom, David Canning and Jaypee Sevilla considering in there work "Economic Growth and the Demographic Transition" the relationship between population change and economic development in particular regions of the world: East Asia; Japan; OECD, North America and Western Europe; South-central and Southeast Asia; Latin America; Middle East and North Africa; Sub-Saharan Africa; and Eastern Europe they come to the conclusion that it is necessary to carry out the corresponding population policies of the countries, since the age structure of the country's population, which is characterized by the economic activity of people at different stages of life, can have a significant impact on the country's economic development and competitiveness (David et al, 2001). The authors' study is based on three main hypotheses: 1) population growth restricts economic development (the pessimistic theory); 2) population change can fuel economic growth (the optimistic theory); 3) population change has no significant effect on economic growth (the neutralist theory. An additional factor of the country's economic growth is the level of education of its population (Lutz et al., 2008). The use of the modified Cobb-Douglas model in the work (Odit, 2010) allowed the authors to conclude that one of the explanations for the impressive growth factors of Mauritius GDP in the period 19902006 was the education of the population, it really serves as an instrument for increasing labor productivity. The analysis of the main determinants of economic growth in more than 100 countries between 1960 and 1995 showed a positive relationship between economic growth and the starting level of average years of school attainment of adult males at the secondary and higher levels та insignificantly related to years of school attainment of females at the secondary and higher levels (Barro, 2000).

The purpose of the article is to determine the influence of social factors on macroeconomic stability.

\section{Results}

The global financial and economic crisis, the processes of globalization, the growth of the need for limited resources, the aging of the society determined the need for the new member states to implement the structur- 
al reforms, based on the transition from the paradigm of the continuous social and economic development of the concept of sustainable development (EPSC, 2016). One of the key documents that reflected the principles of sustainable development in the post-crisis was the Europe 2020 strategy (European Commission, 2010). The Europe 2020 strategy was adopted in 2010 lays the groundwork for the adoption by EU member countries of policy investing in education and human potential, and does so in a manner that favors the protection of the environment and achieves reasonable and sustainable economic growth. The main driver and source of balanced development is human capital, therefore accepted by Ukraine the vector of European development should take into account the relevant main trends in the implementation of economic growth policies. As noted by the authors of the work (Ukraine, 2017), the factors of security, culture, science, education, and healthcare acquire urgent attention from the position of the future development of Ukraine.

Considering the above, we propose to use the integral Human Asset Index (HAI), which is calculated based on three basic subindices "Life, Health, Well-being", "Science, Education, Culture", "Freedom, Equality, Safety" and considers the factors of security, culture, science, education, health:

$H A I=\sqrt[3]{\mathrm{I}_{L H W} \times \mathrm{I}_{S E C} \times \mathrm{I}_{F E S}}$

where $\mathrm{I}_{L H W}$ is the subindex "Life, Health, Well-being", $\mathrm{I}_{S E C}$ is the subindex "Science, Education, Culture", $\mathrm{I}_{F E S}$ is the subindex "Freedom, Equality, Safety".

Each of the subindexes of formula (4) is calculated as the square root of the arithmetic mean of the sum of squared indicators of the components of the corresponding subindex:

$I_{i}=\sqrt[n]{\prod_{j=1}^{n} X_{j t}}$

where $I_{j}$. is the $i$-th субіндекс, $X_{j t}$ is the corresponding normalized indicator of the $\mathrm{j}$-th indicator for the $\mathrm{t}$-th period of the i-th subindex.

The main stages of calculating the integral Human Asset Index are shown schematically in Figure 1 (see in Appendix).

With this approach of calculating the integral Human Asset Index (HAI), the use of a single system of indicators allows for a comparative analysis of different countries to identify fluctuations in their development and to carry out the impact assessments on the country's macroeconomic stability.

The sources of information and the method of calculation for each indicator, which we used to build an integral Human Asset Index is presented in Table 4.

Table 4. The calculation and sources of information on variables that are included in the analysis

\begin{tabular}{|c|c|c|c|}
\hline Variable & Calculation & Source & The direction of impact \\
\hline $\begin{array}{c}\text { Human development } \\
\text { index }\end{array}$ & The index ranges from 0 to 1 & $\begin{array}{c}\text { Human Development Report (HDR, } \\
\text { 2016) }\end{array}$ & stimulator \\
\hline $\begin{array}{c}\text { Global hunger index } \\
\text { The index ranges from 0 - the best } \\
\text { score (without starvation) to 100 - } \\
\text { the worst }\end{array}$ & $\begin{array}{c}\text { The International Food Policy } \\
\text { Research Institute (GHI, 2017) }\end{array}$ & destimulator \\
\hline $\begin{array}{c}\text { Prosperity index } \\
\text { total (\% of GDP) }\end{array}$ & $\begin{array}{c}\text { The index ranges from 0 to 100 } \\
\text { of public and private health } \\
\text { expenditure to GDP }\end{array}$ & $\begin{array}{c}\text { Legatum institute (LPI, 2017) } \\
\text { (World Bank, 2017) }\end{array}$ & stimulator \\
\hline $\begin{array}{c}\text { Population ages 15-64 } \\
\text { (\% of total) }\end{array}$ & $\begin{array}{c}\text { Total population between the ages } \\
15 \text { to 64 as a percentage of the total } \\
\text { population }\end{array}$ & $\begin{array}{c}\text { World Development Indicators } \\
\text { (World Bank, 2017) }\end{array}$ & stimulator \\
\hline $\begin{array}{c}\text { Population ages 0-14 } \\
\text { (\% of total) }\end{array}$ & $\begin{array}{c}\text { Population between the ages 0 to 14 } \\
\text { as a percentage of the total } \\
\text { population }\end{array}$ & $\begin{array}{c}\text { World Development Indicators } \\
\text { (World Bank, 2017) }\end{array}$ & stimulator \\
\hline $\begin{array}{c}\text { GNI per capita } \\
\text { (current US\$ }\end{array}$ & $\begin{array}{c}\text { GNI per capita is the gross national } \\
\text { income, converted to U.S. dollars } \\
\text { using the World Bank Atlas } \\
\text { method, divided by the midyear } \\
\text { population }\end{array}$ & $\begin{array}{c}\text { World Development Indicators } \\
\text { (World Bank, 2017) }\end{array}$ & stimulator \\
\hline
\end{tabular}


Table 4 (cont.). The calculation and sources of information on variables that are included in the analysis

\begin{tabular}{|c|c|c|c|}
\hline Variable & Calculation & Source & \multirow{2}{*}{$\begin{array}{c}\text { The direction of impact } \\
\text { destimulator }\end{array}$} \\
\hline $\begin{array}{l}\text { Poverty headcount } \\
\text { ratio at national } \\
\text { poverty lines ( } \% \text { of } \\
\text { population) }\end{array}$ & $\begin{array}{l}\text { National poverty headcount ratio is } \\
\text { the percentage of the population } \\
\text { living below the national poverty } \\
\text { lines. National estimates are based } \\
\text { on population-weighted subgroup } \\
\text { estimates from household surveys }\end{array}$ & $\begin{array}{l}\text { World Development Indicators } \\
\text { (World Bank, 2017) }\end{array}$ & \\
\hline $\begin{array}{l}\text { Life expectancy at } \\
\text { birth, total (years) }\end{array}$ & $\begin{array}{l}\text { Life expectancy at birth indicates } \\
\text { the number of years a newborn } \\
\text { infant would live if prevailing } \\
\text { patterns of mortality at the time of } \\
\text { its birth were to stay the same } \\
\text { throughout its life }\end{array}$ & $\begin{array}{l}\text { World Development Indicators } \\
\text { (World Bank, 2017) }\end{array}$ & stimulator \\
\hline \multicolumn{4}{|c|}{ The subindex "Science, Education, Culture" } \\
\hline $\begin{array}{l}\text { Patent applications, } \\
\text { residents }\end{array}$ & $\begin{array}{l}\text { Patent applications are worldwide } \\
\text { patent applications filed through the } \\
\text { Patent Cooperation Treaty } \\
\text { procedure or with a national patent } \\
\text { office for exclusive rights for an } \\
\text { invention--a product or process that } \\
\text { provides a new way of doing } \\
\text { something or offers a new technical } \\
\text { solution to a problem }\end{array}$ & $\begin{array}{l}\text { World Development Indicators } \\
\text { (World Bank, 2017) }\end{array}$ & stimulator \\
\hline $\begin{array}{l}\text { Global innovation } \\
\text { index }\end{array}$ & $\begin{array}{l}\text { The index is ranged: } \\
\text { from } 0 \text { to } 7(2007-2010) \\
\text { from } 0 \text { to } 100(2011-2017)\end{array}$ & $\begin{array}{c}\text { Cornell University, INSEAD, and } \\
\text { the World Intellectual Property } \\
\text { Organization (GII, 2017). }\end{array}$ & stimulator \\
\hline $\begin{array}{c}\text { Government } \\
\text { expenditure on } \\
\text { education, total ( } \% \text { of } \\
\text { GDP) }\end{array}$ & $\begin{array}{l}\text { General government expenditure on } \\
\text { education (current, capital, and } \\
\text { transfers) is expressed as a percent- } \\
\text { age of GDP }\end{array}$ & $\begin{array}{l}\text { World Development Indicators } \\
\text { (World Bank, 2017) }\end{array}$ & stimulator \\
\hline $\begin{array}{l}\text { Gross enrolment ratio, } \\
\text { tertiary, both sexes } \\
(\%)\end{array}$ & $\begin{array}{l}\text { Gross enrollment ratio is the ratio } \\
\text { of total enrollment, regardless of } \\
\text { age, to the population of the age } \\
\text { group that officially corresponds to } \\
\text { the level of education shown }\end{array}$ & $\begin{array}{l}\text { World Development Indicators } \\
\text { (World Bank, 2017) }\end{array}$ & stimulator \\
\hline $\begin{array}{l}\text { Research and devel- } \\
\text { opment expenditure } \\
(\% \text { of GDP })\end{array}$ & $\begin{array}{l}\text { Expenditures for research and } \\
\text { development are current and capital } \\
\text { expenditures (both public and pri- } \\
\text { vate) on creative work undertaken } \\
\text { systematically to increase } \\
\text { knowledge, including knowledge of } \\
\text { humanity, culture, and society, and } \\
\text { the use of knowledge for new ap- } \\
\text { plications. }\end{array}$ & $\begin{array}{l}\text { World Development Indicators } \\
\text { (World Bank, 2017) }\end{array}$ & stimulator \\
\hline \multicolumn{4}{|c|}{ The subindex "Freedom, Equality, Safety" } \\
\hline $\begin{array}{l}\text { Index of economic } \\
\text { freedom }\end{array}$ & $\begin{array}{l}\text { The index ranges from } 0 \text { (minimum } \\
\text { freedom) to } 100 \text { (maximum free- } \\
\text { dom) }\end{array}$ & The Heritage Foundation (EF, 2018). & stimulator \\
\hline Press Freedom Index & $\begin{array}{l}\text { The index is ranged from } 0 \text { (the best } \\
\text { indicator) to } 100 \text { (the worst indica- } \\
\text { tor) }\end{array}$ & $\begin{array}{l}\text { Reporters Without Borders (PFI, } \\
\text { 2017). }\end{array}$ & destimulator \\
\hline Civil liberties index & $\begin{array}{l}\text { The index ranges from } 1 \text { (maximum } \\
\text { freedom) to } 7 \text { (minimum freedom) }\end{array}$ & The Freedom House (CLI, 2018). & destimulator \\
\hline $\begin{array}{l}\text { International property } \\
\text { rights index }\end{array}$ & The index ranges from 0 to 10 & $\begin{array}{l}\text { DC-based Property Rights Alliance } \\
\text { (IPRI, 2017) }\end{array}$ & stimulator \\
\hline $\begin{array}{l}\text { Networked readiness } \\
\text { index }\end{array}$ & $\begin{array}{l}\text { The index ranges from } 1 \text { (maximum } \\
\text { freedom) to } 7 \text { (minimum freedom) }\end{array}$ & & destimulator \\
\hline
\end{tabular}

Since within the framework of the proposed methodology for calculating the integral HAI, the information base of indices of both stimulants and destimulators is used, the procedure for their normalization acquires the urgency by means of the following formulas:

- for stimulant indicators which increase is accompanied by an increase in the integral HAI: 
$X_{j t}=\frac{k_{j t}}{\max _{t}\left\{k_{j t}\right\}}$

where $k_{j t}$ is the actual value of the $\mathrm{i}$-indicator for the $\mathrm{j}$-th period;

$X_{j t}$ - normalized j-th index for a t-th period.

- for indicators-destimulators, which increase is accompanied by a decrease in the integral HAI:

$X_{j t}=\frac{\max _{t}\left\{k_{j t}\right\}-k_{j t}}{\max _{t}\left\{k_{j t}\right\}-\min \left\{k_{j t}\right\}}$

It should be noted that in the absence of official information on the maximum or minimum value of the proposed indicators in Table 4, we propose to compare them with the development parameters of a specific EU country, which is the most economically powerful in this case.

The properties of these main explanatory indices of the integral HAI and their description are given in Table 5 .

Table 5. Descriptive statistics of the main explanatory indicators of the integral Human Asset Index (based on our own calculations)

\begin{tabular}{|c|c|c|c|c|}
\hline Variable & Mean value & Standard deviation & Minimum value & Maximum value \\
\hline Human development index & 0.7211875 & 0.0237661 & 0.673 & 0.748 \\
\hline Global hunger index & 4.972941 & 2.545208 & 1.9 & 13.7 \\
\hline Prosperity index & 52.75636 & 0.6532274 & 51.75 & 53.93 \\
\hline Health expenditure & 6.776947 & 0.7071699 & 5.588903 & 7.807534 \\
\hline Population ages $15-64$ & 69.52356 & .4272054 & 68.60608 & 70.16267 \\
\hline Population ages $0-14$ & 14.9422 & .8896512 & 14.10357 & 17.11799 \\
\hline GNI per capita & 2265.882 & 1076.691 & 700 & 3800 \\
\hline $\begin{array}{l}\text { Poverty headcount ratio at } \\
\text { national poverty lines }\end{array}$ & 27.21333 & 29.43246 & 3.8 & 83.3 \\
\hline Life expectancy & 69.25442 & 1.381256 & 67.85951 & 71.18951 \\
\hline Patent activity & 3139.882 & 1421.289 & 1601 & 7208 \\
\hline Global innovation index & 23.93727 & 16.94854 & 2.24 & 37.6 \\
\hline $\begin{array}{l}\text { Government expenditure on } \\
\text { education }\end{array}$ & 5.911403 & 0.8269676 & 4.16794 & 7.31364 \\
\hline Gross enrolment ratio & 72.68068 & 12.62112 & 48.70301 & 84.1975 \\
\hline $\begin{array}{l}\text { Research and development } \\
\text { expenditure }\end{array}$ & 0.8792119 & 0.1509864 & 0.61742 & 1.11322 \\
\hline Index of economic freedom & 49.25 & 3.031647 & 45.8 & 55.8 \\
\hline Press Freedom Index & 35.69167 & 11.44866 & 19.3 & 54 \\
\hline Civil liberties index & 2.583333 & .5149287 & 2 & 3 \\
\hline $\begin{array}{lll}\begin{array}{l}\text { International property rights } \\
\text { index }\end{array} & \\
\end{array}$ & 4.06 & .2796824 & 3.4 & 4.3 \\
\hline Networked readiness index & 3.788 & .2482292 & 3.48 & 4.2 \\
\hline
\end{tabular}

With a view to approbation of the methodology we proposed, we calculated the values of HAI and its subindexes for Ukraine in the period 2000-2015 (Table 6).

Table 6. Integral HAI for Ukraine in the period 2000-2015 (based on our own calculations)

\begin{tabular}{|c|c|c|c|c|}
\hline Year & $\begin{array}{c}\text { The subindex "Life, } \\
\text { Health, Well-being" }\end{array}$ & $\begin{array}{c}\text { The subindex "Science, } \\
\text { Education, Culture" }\end{array}$ & $\begin{array}{c}\text { The subindex } \\
\text { "Freedom, Equality, } \\
\text { Safety" }\end{array}$ & $\begin{array}{c}\text { The integral Human } \\
\text { Asset Index }\end{array}$ \\
\hline 2000 & 0.438001 & 0.31474 & 0.478 & 0.403911 \\
\hline 2001 & 0.448497 & 0.339052 & 0.485 & 0.419362 \\
\hline 2002 & 0.41648 & 0.259105 & 0.482 & 0.373284 \\
\hline 2003 & 0.479307 & 0.267234 & 0.511 & 0.403004 \\
\hline 2004 & 0.412642 & 0.336875 & 0.537 & 0.421055 \\
\hline 2005 & 0.416914 & 0.337549 & 0.681909 & 0.457829 \\
\hline 2006 & 0.43329 & 0.337559 & 0.693269 & 0.466312 \\
\hline 2007 & 0.51921 & 0.332889 & 0.655212 & 0.48381 \\
\hline 2008 & 0.563385 & 0.33304 & 0.605088 & 0.484217 \\
\hline 2009 & 0.588606 & 0.324972 & 0.588305 & 0.482789 \\
\hline 2010 & 0.569229 & 0.242975 & 0.52361 & 0.416824 \\
\hline 2011 & 0.56961 & 0.294811 & 0.50478 & 0.43928 \\
\hline
\end{tabular}


Table 6 (cont.). Integral HAI for Ukraine in the period 2000-2015 (based on our own calculations)

\begin{tabular}{|c|c|c|c|c|}
\hline Year & $\begin{array}{c}\text { The subindex "Life, } \\
\text { Health, Well-being" }\end{array}$ & $\begin{array}{c}\text { The subindex "Science, } \\
\text { Education, Culture" }\end{array}$ & $\begin{array}{c}\text { The subindex } \\
\text { "Freedom, Equality, } \\
\text { Safety" }\end{array}$ & $\begin{array}{c}\text { The integral Human } \\
\text { Asset Index }\end{array}$ \\
\hline 2012 & 0.567057 & 0.308142 & 0.500701 & 0.443934 \\
\hline 2013 & 0.586373 & 0.308142 & 0.533333 & 0.458466 \\
\hline 2014 & 0.600309 & 0.29108 & 0.542448 & 0.455948 \\
\hline 2015 & 0.585397 & 0.149037 & 0.514046 & 0.35529 \\
\hline Coefficient of variation & $14.41 \%$ & $16.79 \%$ & $12.88 \%$ & $8.92 \%$ \\
\hline
\end{tabular}

It should be noted that the analysis of the variation of these subindexes and the integral Human Asset Index (Table 6) does not exceed 33\%, which makes it possible to characterize the given aggregate as homogeneous. The average level of integral HAI during the entire analyzed period is 0.44 units, corresponding to a moderate level of development. After analyzing the data given in Table 6, it is fair to say that one of the factors restraining the positive dynamics of the integral Human Asset Index were the components of the subindex "Science. Education. Culture" the average level of which during the analyzed period was 0.3 units and was marked by the greatest variability.

To check the statistical significance of the relationship between social factors on macroeconomic stability, we suggest using the model proposed in the paper (Melnyk, 2018), which can be written in the form of a regression equation:

$M I=\alpha+\beta(H A I)+\delta(\mathrm{Z})+\varepsilon$,

where $M I$ is an integral indicator of macroeconomic stability (Vasylieva, 2018), which is based on the methodology for determining the average arithmetic normalized indicators: 1) the ratio of the fiscal deficit to GDP ratio; 2) the sum of the unemployment and inflation rates; 3 ) the ratio of the external debt-to-GDP ratio (Briguglio et al., 2009); $Z$ is a vector of variables that explain the behavior of macroeconomic stability over time (the openness of the economy measured as the percentage of total trade to GDP (Openness), прямі іноземні інвестиції (FDI)); $\alpha, \beta$ and $\delta$ are the constants of the equation; $\varepsilon$ is the error associated with the approximation of the model and the stochasticity of its factors.

Considering the data given in Table 7, the results of the evaluation of the impact of social factors on the macroeconomic stability of Ukraine for the period 2000-2015, the regression equation (8) can be written as follows:

Table 7. The results of assessment of the impact of social factors on Ukrainian macroeconomic stability for the period 2000-2015 (based on our own calculations)

\begin{tabular}{|c|c|c|c|c|c|}
\hline Source | & $d f$ & MS & Number of obs $=$ & \multicolumn{2}{|c|}{16} \\
\hline & & 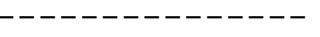 & $F(4$, & $=$ & 9.04 \\
\hline Model | & .653552027 & .163388007 & Prob $>F$ & $=$ & 0.0017 \\
\hline Residual | & .198767859 & .018069805 & $\mathrm{R}$-squared & $=$ & 0.7668 \\
\hline--------+ & & ----------- & Adj R-squared & $=$ & 0.6820 \\
\hline Total | & .852319885 & .056821326 & Root MSE & $=$ & .1344 \\
\hline
\end{tabular}

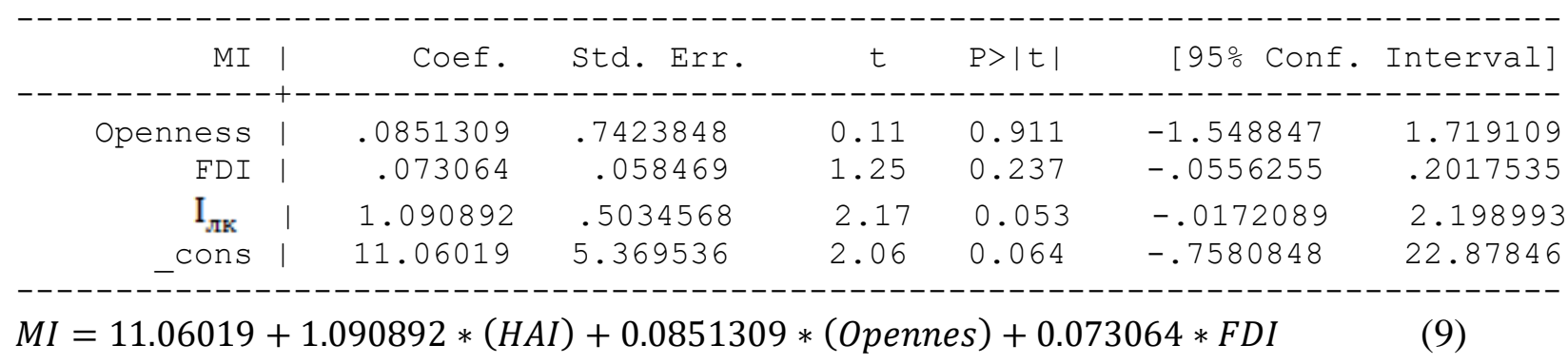

According to the main results, the empirical findings of the study indicate a positive and statistically significant relationship at the level of 5\% between social factors and macroeconomic stability of Ukraine in the period 2000-2015. The results of the empirical study show that the growth of the integral human asset index HAI by $1 \%$ increases the level of macroeconomic stability by more than $1.09 \%$. The selected set of factors 
almost by $77 \%$ percent describes the dynamics of changes in Ukrainian macroeconomic stability during 2000-2015.

The results of calculating the integral human asset index serve as an information base for the introduction of appropriate measures to increase the country's macroeconomic stability.

\section{Conclusions}

The last global financial and economic crisis has led to the acceleration in the growth rates of disproportions in the socio-economic development of countries. The two main negative aspects of the impact of the crisis were the experience of high and stable rates of unemployment and the growth of social inequality. As the analysis showed, the excess of $10 \%$ of the average unemployment rate for the last three years occurred in Greece (14.97\%), Spain (12.03\%), Croatia (5.53\%), Cyprus (4, 67\%), Portugal (2.47\%), Slovakia (1.47\%), France $(0.27 \%)$. The lowest average annual unemployment rate in the last three years was recorded in Germany (4.57\%), Austria (5.77\%), the Czech Republic (5.03\%), Great Britain (5.4\%), Malta (5.3\%), the living standard, measured by gross domestic product per capita in the period 2008-2016 remains statistically lower than in the pre-crisis period.

One of the main reasons for such negative impacts of the recent financial and economic crisis on the economies of the EU member states was macroeconomic instability. Therefore, in the context of identifying factors that enhance macroeconomic stability, social factors take on a special place. The authors, based on the experience of the EU member states, have determined that the factors of security, culture, science, education, and healthcare are of vital importance from the perspective of future development of Ukraine. In particular, the development of the indicator of the level of the country's human capital as a target for the construction of an appropriate monitoring system and, in the future, the implementation of measures of stabilization macroeconomic policy is of great importance.

It was noted that along with significant progress in ensuring an even distribution of income among the population in Ukraine, the current trend of 2014-2017 and the level of the minimum wage is several times behind that of the EU member states. Since 2007 the unemployment rate for the first time was $0.7 \%$ higher than the average for the EU countries (in $2016-8.7 \%$ ).

The structural scheme of an estimation of integrated human asset index which consists of five basic stages is developed in the work: identification of relevant indicators which will be formed by each of subindexes; filtering selected at the previous stage relevant indicators based on the analysis of the correlation matrix of each of the subindexes; normalization of indicators in each of the subindexes, calculation of the integral indicator for each of the subindexes, calculation of the final integral human asset index.

The proposed integral human asset index allows us to provide a quantitative assessment of the level of development of security factors, culture, science, education, health, whose target point should be considered its approximations to unity.

The calculation of integral human asset index for Ukraine for 2000-2015 showed that one of the factors restraining the positive dynamics of the integral human asset index were the components of subindex "Science. Education. Culture", the average level of which during the analyzed period was 0.3 units and was marked by the greatest variability. In general, in Ukraine, the average level of the integral index HAI throughout the analyzed period was 0.44 units, corresponding to a moderate level of development. At the same time, the empirical findings of the study of the influence of the integral index $H A I$ on the macroeconomic stability of Ukraine in the period 2000-2015 evidenced a positive and statistically significant relationship at 5\% between them. The results obtained assert that growth of integral human asset index $H A I$ by $1 \%$ increases the level of macroeconomic stability more than by $1.09 \%$.

\section{References}

1. Ukraine 2030: Doctrine of the balanced development (2017). scientific editor Zhylins'ka O., managing editor Mel'nychuk O. [Ukrayina 2030: Doktryna zbalansovanoho rozvytku, naukovyy redaktor Zhylins'ka O., vidpovidal'nyy redaktor Mel'nychuk O.], L'viv, Ka'variya, 164 p. [in Ukrainian].

2. Abdul-Khaliq, S., Soufan, T., \& Shihab, R. A. (2014). The relationship between unemployment and economic growth rate in Arab Country. Journal of Economics and Sustainable Development, ISSN, 22221700 . 
3. Al-Habees, M. A., \& Rumman, M. A. (2012). The relationship between unemployment and economic growth in Jordan and some Arab countries. World Applied Sciences Journal, 18(5), 673-680.

4. Barro, R. J. (2000). Education and Economic Growth, mimeo, Harvard University. Retrieved from: https://scholar.harvard.edu/files/aghion/files/causal_impact_of_education.pdf.

5. Bloom, D. E., Canning, D., \& Sevilla, J. (2001). Economic growth and the demographic transition. National Bureau of Economic Research, No. w8685. Retrieved from : http://www.nber.org/papers/w8685.

6. Briguglio, L., Cordina, G., Farrugia, N., \& Vella, S. (2009). Economic vulnerability and resilience: concepts and measurements. Oxford development studies, 37(3), 229-247.

7. Buti, Marco (2011). Balancing Imbalances: Improving Economic Governance in the EU after the Crisis, CESifo Forum, ISSN 2190-717X, Vol. 12, Iss. 2, 3-11

8. Castells-Quintana, D., \& Royuela, V. (2012). Unemployment and long-run economic growth: The role of income inequality and urbanisation. Investigaciones Regionales, 24, 153-173.

9. Cingano, F. (2014). Trends in income inequality and its impact on economic growth. OECD Social, Employment and Migration Working Papers, № 163. Retrieved from : http://www.oecd-ilibrary.org/socialissues-migration-health/trends-in-income-inequality-and-its-impact-on-economic-growth_5jxrjncwxv6jen

10. CLI (2018). Civil liberties index. The Freedom House. Retrieved from : https://freedomhouse.org/reporttypes/freedom-world

11. EF (2018). Index of economic freedom. The Heritage Foundation. Retrieved from: https://www.heritage.org/index/

12. EPSC, (2016). Sustainability Now! A European Vision for Sustainability. European Political Strategy Centre, Issue 18. Retrieved from : http://ec.europa.eu/epsc/sites/epsc/files/strategic_note_issue_18.pdf.

13. European Commission (2015b). Adding employment indicators to the scoreboard of the Macroeconomic Imbalance Procedure to better capture employment and social development, Brussels, 4 September 2015, Retrieved from: http://ec.europa.eu/economy_finance/economic_governance/documents/ employment_indicators_mip_en.pdf.

14. European Commission (EC). (2010). Europe 2020: a strategy for smart, sustainable and inclusive growth. Working paper $\{C O M \quad$ (2010) 2020\}. Retrieved from: http://ec.europa.eu/eu2020/pdf/COMPLET\%20EN\%20BARROSO\%20\%20\%20007\%20$\% 20$ Europe \%202020\%20-\%20EN\%20version.pdf.

15. Eurostat (2017). European statistics. Retrieved from : http://ec.europa.eu/eurostat/data/database.

16. GHI, (2017). Global Hunger Index. The International Food Policy Research Institute (IFPRI). Retrieved from : http://www.ifpri.org/publication/concept-global-hunger-index-1.

17. GII, (2017). Global innovation index. Cornell University, INSEAD and the World Intellectual Property Organization Retrieved from : https://www.globalinnovationindex.org/analysis-indicator.

18. Gnade, H., Blaauw, P. F., \& Greyling, T. (2017). The impact of basic and social infrastructure investment on South African economic growth and development. Development Southern Africa, 34(3), 347364.

19. HDR, (2016). Human Development Report. United Nations Development Program. Retrieved from : http://hdr.undp.org/en/content/human-development-index-hdi.

20. IPRI, (2017). The International Property Rights Index. DC-based Property Rights Alliance (PRA). Retrieved from : https://www.internationalpropertyrightsindex.org/full-report.

21. Leonid Melnyk, Lina Sineviciene, Oleksii Lyulyov, Tetyana Pimonenko and Iryna Dehtyarova (2018). Fiscal decentralization and macroeconomic stability: the experience of Ukraine's economy. Problems and Perspectives in Management, 16(1), 105-114.

22. LPI, (2017). The Legatum Prosperity Index. Legatum institute. Retrieved from : http://www.prosperity.com/rankings

23. Lutz, W., Cuaresma, J. C., \& Sanderson, W. (2008). The demography of educational attainment and economic growth. Population, 25(29), 15-19.

24. More, I., \& Aye, G. C. (2017). Effect of social infrastructure investment on economic growth and inequality in South Africa: a SEM approach. International Journal of Economics and Business Research, 13(2), 95-109.

25. Nagel, K. (2015). Relationships between unemployment and economic growth-the review (results) of the theoretical and empirical research. Journal of Economics \& Management, 20, 64-79.

26. Odit, M. P., Dookhan, K., \& Fauzel, S. (2010). The impact of education on economic growth: The case of Mauritius. The International Business \& Economics Research Journal, 9(8), 141-152. 
27. PFI, (2017). Press Freedom Index. Reporters Without Borders (RSF). Retrieved from : https://rsf.org/en/detailed-methodology.

28. Popa, A. M. (2012). The impact of social factors on economic growth: Empirical evidence for Romania and European Union countries. Romanian Journal of Fiscal Policy (RJFP), 3(2), 1-16.

29. Ukrainy, D. (2017). State statistics Service of Ukraine. Available at: http://www.ukrstat.gov.ua [in Ukrainian].

30. Vasylieva, T., Lyeonov, S., Lyulyov, O., \& Kyrychenko, K. (2018). Macroeconomic Stability and Its Impact on the Economic Growth of the Country. Montenegrin Journal of Economics, 14(1), 159-170.

31. World Bank (2017). World Development Indicators, World Bank. Retrieved from : https://data.worldbank.org/indicator.

32. World of Work Report (2008). Income Inequalities in the Age of Financial Globalization. International Labour Office, International Institute for Labour Studies. Geneva: ILO, $180 \mathrm{p}$.

33. You, J. \& Khagram, S. (2005). A comparative study of inequality and corruption. American Sociological Review, 70(1), 136-157. 


\section{Appendix}

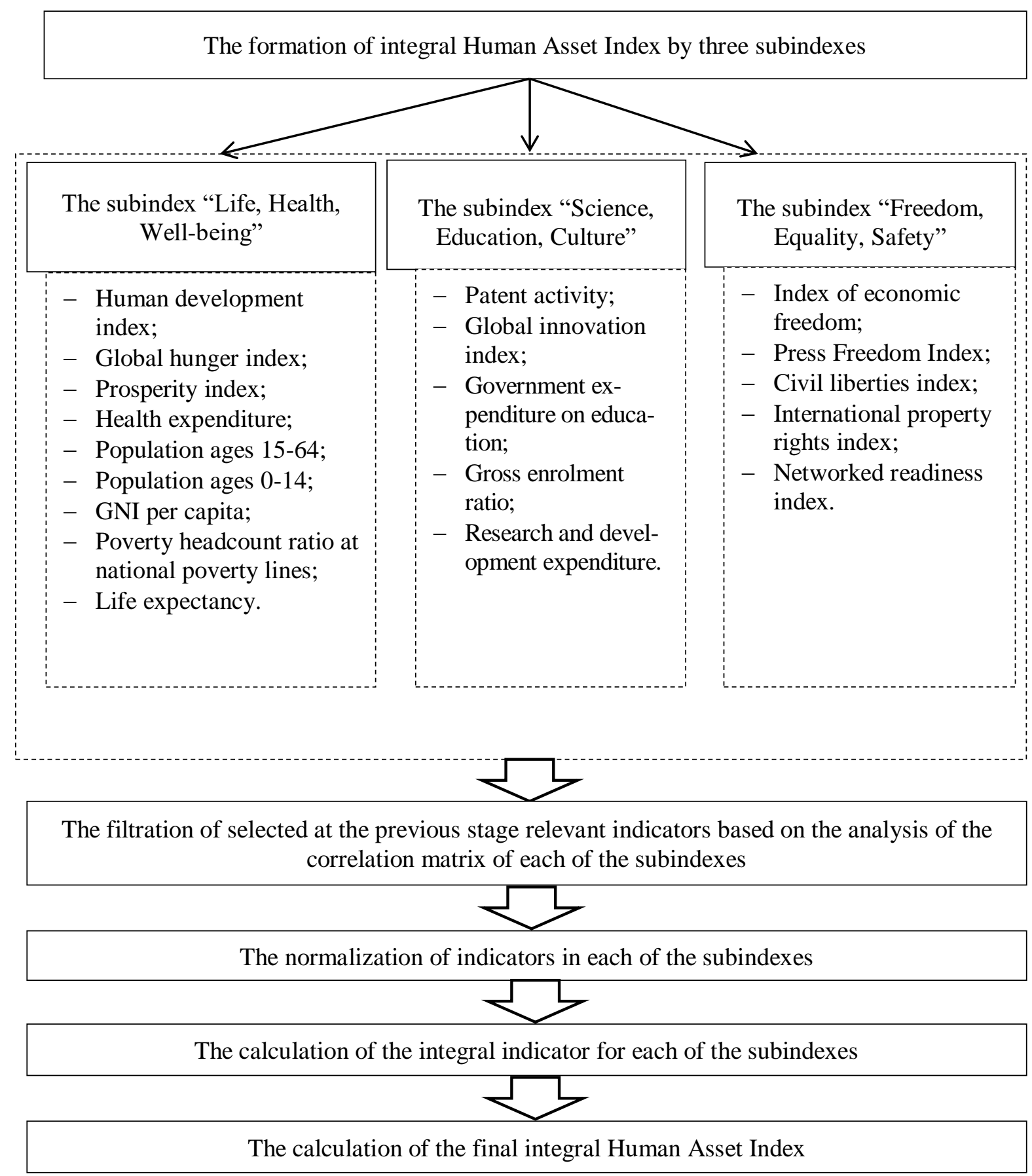

Source: based on (Ukraine, 2017).

Figure 1. Structural diagram of the evaluation of the integral Human Asset Index 